\title{
Kurutulmuş Organik Kuru Üzüm Meyvelerinde Farklı Ambalajların Raf Ömrü Süresince Kaliteye Etkileri
}

\author{
Hasan KURUÇAYLI' (D, Fatih ŞEN*2 \\ 'Işık Tarım Ürünleri San. ve Tic. A.Ş., Kemalpaşa, iZMiR. \\ ${ }^{2}$ Ege Üniversitesi, Ziraat Fakültesi, Bahçe Bitkileri Bölümü, Bornova, iZMiR.
}

Özet: Çalışma, farklı ambalajlarla paketlenen organik kuru üzüm meyvelerinin raf ömrü süresince kalite değişimlerini belirlemek amacıyla yürütülmüştür. Potasyum karbonat çözeltisine bandırılarak ve bandırılmadan güneşte kurutulan organik kuru üzümler (cv. Sultani Çekirdeksiz) kraft box, doypack, quadro, lunch box ve pillow pack ambalajlarına yerleştirilmiştir. Kuru üzüm meyvelerinin konduğu ambalajlar $20 \pm 1{ }^{\circ} \mathrm{C}$ 'de \%50-65 oransal nemde 9 ay süreyle muhafaza edilmiştir. Ambalaj çeşidinin kuru üzüm meyvelerin nem miktarını etkileyerek suda çözünür kuru madde miktarı ve su aktivitesinde artış veya azalışlara neden olduğu saptanmıştır. Meyvelerdeki nem miktarı, kuru üzümde quadro ambalajında en yüksek, kraft box ambalajında ise en düşük bulunmuştur. Genel olarak ambalajların organik kuru üzümlerin rengine ve incelenen diğer kalite parametrelere etkileri sınırlı olmuştur. Sonuçlar, quadro ambalajın ise kuru üzümde önerilebileceği, kraft box ambalajlarında bazı kalite parametreleri ile ilgili sorunlar yaşanabileceğini göstermiştir.

Anahtar Kelimeler: organik kuru meyve, depolama, ambalaj, dayanım, nem miktarı

\section{Effect of Different Packages on Dried Grape Organic Fruit Quality During Shelf Life}

Abstract: The study was conducted to determine quality changes of organic dried grapes packaged in different packages throughout shelf life. Organic grapes (cv. Sultanas seedless) sun-dried after dipping or without dipping into potassium carbonate solution were placed in craft box, doypack, lunch box and pillow pack packages. Dried grapes were stored at $20 \pm 1^{\circ} \mathrm{C}$ and $50-65 \%$ relative humidity for 9 months. Package type is found to affect the moisture content of dried grapes and accordingly increase or decrease the quantity of water, total soluble solids and water activity. Water content was the highest in quadro package for dried grapes and was the lowest in craft box package dried grapes. In general, effects of packages on colour and other quality parameters analyzed were rather limited. Results showed that dried grapes packed in quadro package may be offered. There might be problems in craft box packages related to some quality parameters.

Keywords: organic dried fruits, storage, package, storability, moisture content

\section{GiRiș}

Tarımsal ürünlerin güneşte kurutularak saklanması binlerce yıldan beri uygulanmakta olan bir değerlendirme şeklidir. Su kaybeden ürünün hacimce küçülmesi, böylece taşıma ve depolama maliyetlerinin azalması, normal koşullarda uzun süre kolayca saklanabilmesi nedeni ile kurutma günümüzde de birçok üründe uygulanmaktadır (Cemeroğlu ve ark., 2004). Kuru ürünün daha uzun süreyle normal koşullarda depolanabilmesi nedeni ile pazarlamada esneklik sağlamakta ve yeni kullanım alanları yaratmaktadır. Birçok kurutulmuş meyve sofralık tüketim yanında bisküvi, pasta, müsli, süt ve mamulleri, çikolata, kahve vb. gıda sanayiinde hammadde veya katkı maddesi olarak kullanılabilmektedir.

Türkiye 2015 yılında 224,000 ton kuru üzüm üretiminin yaklaşık 19,000 tonu organik, 20.000 tonu organik ürüne geçiş aşamasındadır (Anonim, 20l6a). Organik kuru üzümün \%22'si ihraç edilerek 14 milyon \$ gelir elde edilmektedir (Anonim, 20l6b). Dünya organik kuru meyve ticaretinde Türkiye payın korumak ve arttırmak için ürün kalitesindeki kararsızlıkları ortadan kaldırmalı ve tüketici taleplerinde ortaya çıkan değişimlere ayak uydurması gerekmektedir. Üretilen organik sertifikalı ürünlerin tamamına yakını başta $A B$ ülkeleri, $A B D$ ve Japonya olmak üzere gelişmiş ülkelere ihraç edilmektedir. Başlangıçta organik tarımın gelişmesine yardımcı olan kuru ve kurutulmuş meyveler pazarında Türkiye lider ülke konumundadır.

Organik tarımsal üretim ve pazarlama, kendine özgü uluslararası kuralları olan, izlenebilir, kayıtlı ve şeffaf bir süreçtir. Organik ürünler bu sürecin tüm aşamalarında bağımsız kontrol ve sertifikasyon kuruluşları tarafından kontrol edilir ve sertifikalandırıır (Demiryürek, 2000; Demiryürek ve ark., 2008). Organik tarımın amacının tüketici sağlığını koruma, onların tercihlerini dikkate alma, toprak verimliliğini koruma, toprak, bitki, hayvan ve çiftlik sistemleri arasındaki besin zincirini düzenleme gibi unsurları içerdiğinden ilaç, gübre, büyüme düzenleyiciler ve hormonlar gibi kimyasal, çözülebilir ve inorganik maddelerin kullanımı yasaklanmaktadır.

Organik kuru meyvelerde ortaya çıkan en önemli olumsuzluk, renk esmerleşmesidir. Renk esmerleşmesi kurutmadan önce, kurutma sırasında, depolama ve raf ömrü sürecinde oluşur. Renk esmerleşmesi enzimatik veya enzimatik olmayan reaksiyonlar sonucu olabilir. Kuru meyvelerdeki bu renk değişiminde sıcaklık ve nem miktarı önemli rol oynamaktadır (Fennema, 1976; Cemeroğlu ve ark., 2004). Bu nedenle raf ömrü koşullarında kararma düşük sıcaklıklarda depolamaya göre çok daha belirgin olmaktadır (Sen ve ark., 2009).

Organik kuru ürünlerde renk dışında, görünüş, tekstür, rehidrasyon özelliği, tat ve aroma, mikrobiyal yük ve zararlılardan arilik de önemli kalite parametreleridir (Perera, 2005). Organik kuru üzümlerin hasat sonrası pazarlama sürecinde görülen bu bozulmalarda ambalajlama şekli ve kullanılan ambalajlama materyalinin özelliği de büyük önem taşımaktadır. Ambalajın oksijen ve nem geçirgenliğinin kuru meyvelerin depolama ömrünü etkilediği değişik çalışmalarda rapor edilmiştir (Yeygel, 200 I; Altuğ ve ark., 2003; Şen ve ark., 2007; Elmacı ve ark., 2008). Organik kuru üzüm meyvelerinin ambalajlanması, depolama ve raf ömrü koşullarında gereken

*Sorumlu Yazar: fsenmacar@gmail.com

Bu çalışma yüksek lisans tezi ürünüdür.

Geliş Tarihi: 6 Temmuz 2017

Kabul Tarihi: 29 Kasım 2017 
özen gösterilmemesi durumunda ürünün besin değerive duyusal kalitesi özellikleri üzerinde olumsuzluklar görülebilmektedir. Bu olumsuzluklar raf ömrü süresinin uzamasıyla daha belirgin hale gelmektedir. Kuru üzüm meyvelerinde önemli fiziksel, kimyasal ve mikrobiyolojik bozulmalar gözükebildiğinden tüketilebilirliğini kaybedebilmektedir.

Çalışma; farklı ambalaj materyallerinin, paketlenen organik kuru üzüm meyvelerinin raf ömrü süresince kalite değişimlerine etkilerinin ortaya konması amacıyla yürütülmüştür.

\section{MATERYAL ve YÖNTEM \\ Materyal}

Çalışmada organik olarak üretilen üzüm meyvelerinin kurutulmasıyla elde edilen kuru üzümler ile yürütülmüştür.

Bandırılmış kuru üzümler; Manisa ili Merkez Karaoğlanlı köyü 45K-003 çiftçi kodlu üretici tarafından organik olarak yetiştirilen Sultani Çekirdeksiz üzüm çeşidinin salkımlarının potas çözeltisine (potasyum karbonat, $\mathrm{K}_{2} \mathrm{CO}_{3}$ ) bandırılarak güneşte kurutulmasıyla elde edilmiştir. Bandırılmamış kuru üzümler; Manisa ili Ahmetli ilçesi Karaköy köyünde MMU-02 I çiftçi kodlu üretici tarafından organik olarak yetiştirilen Sultani Çekirdeksiz üzüm çeşidinin salkımlarının güneşte kurutulmasıyla elde edilmiştir. Sultani Çekirdeksiz üzüm çeşidinin salkımları orta irilikte (300-400 g) ve normal sıklıktadır. Taneleri küçük (।.2-I.8 g), yeşil-sarı renkte, ince kabukludur (Anonim, 1990). Hasatta suda çözünür kuru madde (SÇKM) oranı \%22-23'tür (Akdeniz, 20ll).

3 yıllık geçiş sürecini tamamlamış organik kuru üzüm örneklerinin tüm üretimdeki kontrol ve sertifikasyon işlemleri Kiwa BCS Öko-Garantie Organik Tarım Sertifikalandırma Hizmetleri Ltd. Şti. tarafından yapılmıştır.

Organik kuru üzümler, zararlı kontrolleri için atmosferik koşullarda $\mathrm{CO}_{2}$ uygulaması yapıldıktan sonra 5 ay süreyle 4-5 ${ }^{\circ} \mathrm{C}$ sıcaklık \%60-65 oransal nemdeki soğuk hava deposunda işleme ve paketlemeye kadar muhafaza edilmiştir. Ürünlerde işleme öncesi yapılan ön incelemelerde zararlı yönünden herhangi bir bulgu görülmediğinden doğrudan işleme alınarak sırasıyla boylama, yıkama, işleme (laser, $X$ ray kontrolleri), paketleme işlemleri yapılmıştır.

\section{Ambalaj Özellikleri ve Raf Ömrü Koşulları}

Organik kuru üzümün pazarlama sürecinde kullanılan ve yeni geliştirilen ambalajlar dikkat alınarak ürünler pazara sunulacak şekilde paketlenmiştir. Bu ürünlerin paketlenmesinde kullanılan ambalajların özellikleri aşağıda verilmiştir.

Kraft box: Karton + PO'den (polyolefin = selefon) oluşmakta, kalınlığı $2 \mathrm{~mm}$, boy $10 \mathrm{~cm}$, en $7.5 \mathrm{~cm}$, yükseklik $3.5 \mathrm{~cm}$ ve ağırlı̆̆ 20 g'dır.

Doypack: Polietilen tereftalat $(\mathrm{PET})+$ alüminyum $(\mathrm{AL})+$ polietilen (PE)'den yapılmış, kalınlığı 130 mikron, $\mathrm{O}_{2}$ geçirgenliği $<0.0002 \mathrm{cc} / \mathrm{I}$ Atm. $/ 24 \mathrm{~h} / \mathrm{m}^{2}$, boy $18 \mathrm{~cm}$, en $15 \mathrm{~cm}$ ve ağırlığı 9 g'dır.

Quadro: PET ve oryante edilmemiş polipropilen (CPP)'den yapılmış, kalınlığı 62 mikron, $\mathrm{O}_{2}$ geçirgenliği I I 0 cc/I Atm./24 $\mathrm{h} / \mathrm{m}^{2}$, boy $2 \mathrm{l} \mathrm{cm}$, en $9.5 \mathrm{~cm}$, ağırlığı $3 \mathrm{~g}$ ve ürün yerleştirildikten sonra kalınlığı $7 \mathrm{~cm}$ 'dir.

Lunch box (Küçük kutucuk): Kartondan yapılmış, kalınlığı I $\mathrm{mm}$, boy $7.5 \mathrm{~cm}$, en $5.5 \mathrm{~cm}$, genişlik $2 \mathrm{~cm}$ ve ağırlığı 4 g'dır.

Pillow pack (Yastık poşet): PET + CPP kartondan yapılmış, kalınlığı 62 mikron, $\mathrm{O}_{2}$ geçirgenliği $110 \mathrm{cc} / \mathrm{I}$ Atm. $/ 24 \mathrm{~h} / \mathrm{m}^{2}$, boy $15.5 \mathrm{~cm}$, en $16 \mathrm{~cm}$, ağırlığı 6 g'dır.
Farklı ambalajlarla paketlenmiş olan organik kuru üzümler aynı gün içinde Ege Üniversitesi Ziraat Fakültesi Bahçe Bitkileri Bölümü'ne getirilerek, $20 \pm 1^{\circ} \mathrm{C}$ 'de $\% 50-65$ oransal nemdeki raf ömrü koşullarında 9 ay süreyle saklanmıştır. Organik kuru üzümlerden 3 ay aralıklarla alınan örneklerde fiziksel, kimyasal, duyusal analizler yapılmış ve böcek gelişimi izlenmiştir. Çalışma tesadüf parselleri deneme desenine göre üç tekrarlı olarak planlanmış olup, bandırılmış (Sultana) ve bandırılmamış (Raisin) kuru üzümler kullanılmıştır. 6 adet lunch box bir tekerrür, diğer ambalajlarda ise her bir ambalaj bir tekerrür olarak kabul edilmiştir.

\section{Kalite Analizleri}

Tane Rengi

Üzüm tanelerinin rengi, Minolta kolorimetre (CR-400, Minolta Co., Tokyo, Japonya) ile CIE $L^{*} a^{*} b^{*}$ cinsinden ölçülmüştür. Elde edilen $a^{*}$ ve $b^{*}$ değerlerinden kroma $\left(C^{*}\right)$ ve hue açısı $\left(h^{\circ}\right)$ değerleri $C^{*}=\left(a^{* 2}+b^{* 2}\right)^{1 / 2}$ ve $h^{\circ}=\tan ^{-1}\left(b^{*} / a^{*}\right)$ formüllerine göre hesaplanmıştır. $C^{*}$ değeri rengin doygunluğunu göstermektedir $\left(0=\right.$ mat, $60=$ doygun). $h^{\circ}$ değeri CIE $L^{*} a^{*} b^{*}$ skalasında açı koordinatıdır $\left(0^{\circ}=\right.$ kırmızı-mor, $90^{\circ}=$ sarı, $180^{\circ}$ = mavimsi yeşil ve $270^{\circ}=$ mavi) (McGuire, 1992).

\section{Su Miktarı}

Her tekerrürden alınan organik kuru üzümler kıyma makinesinden geçirildikten sonra alınan örneğin tartılarak, $65^{\circ} \mathrm{C}$ 'ye ayarlanan etüvde (UM400, Memmert, Almanya) ağırlık sabitleninceye kadar kurutulması ve tekrar tartılması ile \% olarak saptanmıştır (AOAC, 1990).

\section{Su Aktivitesi}

Su aktivitesi $\left(a_{w}\right)$ değeri, kıyma makinesinden geçirilen organik kuru üzüm örneklerinde su aktivitesi ölçer ile (TH 500, Novasina, İsviçre) $25^{\circ} \mathrm{C}$ 'de ölçülmüştür.

\section{Suda Çözünür Kuru Madde Miktarı}

Suda çözünür kuru madde (SÇKM), kıyma makinesinden geçirilmiş kuru üzümde $10 \mathrm{~g}$ örneğe, $100 \mathrm{ml}$ saf su ilave edilmiş ve 4 saat bekletildikten sonra parçalanmış, süzme işlemini takiben SÇKM miktarı dijital refraktrometre (PR-I, Atago, Japonya) ile saptanmış ve elde edilen sonuçlar \% olarak verilmiştir.

\section{Titre Edilebilir Asit Miktarı}

Titre edilebilir asit (TA) miktarını saptamak ve SÇKM okumak için kıyma makinesinden geçirilerek saf su ile parçalanmış süzüntüden yararlanılmıştır. Asit miktarı (Anonim, 1972)'de önerildiği şekilde gerçekleştirilmiştir. Elde edilen sonuçlar hesaplanarak g tartarik asit/l 00 g olarak verilmiştir.

\section{Böcek Zararı}

Böcek zararının olup olmadığı, varsa zararın boyutu ve etmeni Ege Üniversitesi Ziraat Fakültesi Bitki Koruma Bölümü’nde incelenmiştir.

\section{İstatistiksel Analiz}

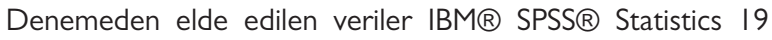
(IBM, NY, USA) istatistik paket programı kullanılarak varyans analizine tabi tutulmuştur. Bandırılmış ve bandırılmamış organik kuru üzüm için her raf ömrü dönemindeki ortalamalar arasındaki farklılıklar ayrı ayrı Duncan testi $(P \leq 0.05)$ ile belirlenmiştir.

\section{BULGULAR ve TARTIŞMA}

\section{Bandırılmış Organik Kuru Üzüm}

Raf ömrü süresince farklı ambalajlardaki bandırılarak kurutulan organik kuru üzüm tanelerinin renk ( $C^{*}$ ve $h^{\circ}$ değeri) değişimleri 
Çizelge I. Farklı ambalajların raf ömrü süresince bandırılmış organik kuru üzüm tanelerinin $C^{*}$ ve $h^{\circ}$ değerine etkileri

\begin{tabular}{|c|c|c|c|c|c|c|}
\hline \multirow[b]{2}{*}{ Ambalaj } & \multicolumn{3}{|c|}{$C^{*}$} & \multicolumn{3}{|c|}{$h^{\circ}$} \\
\hline & 3. Ay & 6. Ay & 9. Ay & 3. Ay & 6. Ay & 9. Ay \\
\hline Kraft box & $16.59^{\circ \text { o.d. }}$ & $16.17^{0 . d}$ & $15.47^{\circ \text { o.d. }}$ & $67.74^{\text {ö.d. }}$ & $58.82^{\text {o.d. }}$ & $55.86^{\circ 0 . d}$ \\
\hline Doypack & 16.39 & 15.14 & 16.19 & 68.24 & 58.53 & 57.96 \\
\hline Quadro & 16.91 & 16.43 & 15.99 & 68.55 & 60.24 & 58.79 \\
\hline Lunch box & 16.98 & 15.34 & 15.32 & 69.42 & 60.85 & 57.04 \\
\hline Pillow pack & 17.19 & 17.01 & 16.95 & 69.75 & 57.84 & 59.66 \\
\hline
\end{tabular}

ö.d.: önemli değil

Çizelge 2. Farklı ambalajların raf ömrü süresince bandırılmış organik kuru üzüm tanelerinin su miktarına ve $\mathrm{a}_{\mathrm{w}}$ değerine etkileri

\begin{tabular}{|c|c|c|c|c|c|c|}
\hline \multirow[b]{2}{*}{ Ambalaj } & \multicolumn{3}{|c|}{ Su miktarı (\%) } & \multicolumn{3}{|c|}{ a değeri } \\
\hline & 3. Ay & 6. Ay & 9. Ay & 3. Ay & $6 . A y$ & 9. Ay \\
\hline Kraft box & $14.98 c^{2 * * *}$ & $13.82 c^{* * *}$ & $13.55 c^{\text {*** }}$ & $0.47^{c} z^{* *}$ & $0.49 c^{* *}$ & $0.49 c^{* * *}$ \\
\hline Doypack & $16.48 \mathrm{~b}$ & $15.62 \mathrm{ab}$ & $4.22 \mathrm{~b}$ & $0.53 \mathrm{~b}$ & $0.50 \mathrm{bc}$ & $0.52 \mathrm{~b}$ \\
\hline Quadro & $17.79 \mathrm{a}$ & $16.65 \mathrm{a}$ & $15.19 \mathrm{a}$ & $0.57 \mathrm{a}$ & $0.55 \mathrm{a}$ & $0.55 \mathrm{a}$ \\
\hline Lunch box & $16.21 \mathrm{~b}$ & $15.17 \mathrm{~b}$ & $14.41 \mathrm{~b}$ & $0.53 b$ & $0.52 b$ & $0.50 \mathrm{bc}$ \\
\hline Pillow pack & $16.31 \mathrm{~b}$ & $15.78 \mathrm{ab}$ & $13.96 \mathrm{bc}$ & $0.53 \mathrm{~b}$ & $0.53 \mathrm{ab}$ & $0.51 \mathrm{bc}$ \\
\hline
\end{tabular}

${ }^{z}$ Her sütunda ortalamalar arasındaki farklılıklar Duncan testiyle $P \leq 0.05$ 'e göre belirlenmiştir.

*** $\mathrm{P} \leq 0.0$ l'e göre önemli.

Çizelge 3. Farklı ambalajların raf ömrü süresince bandırılmış organik kuru üzüm tanelerinin SÇKM ve TA miktarına etkileri

\begin{tabular}{|c|c|c|c|c|c|c|}
\hline \multirow[b]{2}{*}{ Ambalaj } & \multicolumn{3}{|c|}{ SCKM miktarı (\%) } & \multicolumn{3}{|c|}{ TA miktarı (g tartarik asit/100 g) } \\
\hline & 3. Ay & 6. Ay & 9. Ay & 3. Ay & 6. Ay & 9. Ay \\
\hline Kraft box & $69.33 \mathrm{a}^{2 *}$ & 69.67 ö.d. & 73.67ö.d. & $1.58^{c} z^{* *}$ & $1.60 c^{* *}$ & $1.53 c^{* * *}$ \\
\hline Doypack & $65.89 \mathrm{~b}$ & 68.56 & 73.89 & $1.49 \mathrm{c}$ & $1.65 \mathrm{c}$ & $1.57 \mathrm{c}$ \\
\hline Quadro & $64.78 b$ & 68.11 & 73.44 & $1.45 \mathrm{c}$ & $1.59 \mathrm{c}$ & $1.61 \mathrm{c}$ \\
\hline Lunch box & $66.33 \mathrm{ab}$ & 69.00 & 74.33 & $1.71 \mathrm{~b}$ & $1.82 \mathrm{~b}$ & $1.83 \mathrm{~b}$ \\
\hline Pillow pack & $65.22 \mathrm{~b}$ & 67.00 & 73.44 & $1.92 \mathrm{a}$ & $2.03 \mathrm{a}$ & $2.01 \mathrm{a}$ \\
\hline
\end{tabular}

${ }^{z}$ Her sütunda ortalamalar arasındaki farklılıklar Duncan testiyle $P \leq 0.05$ 'e göre belirlenmiştir.

ö..: önemli değil, * $P \leq 0.05$ veya ** $P \leq 0.0$ l'e göre önemli.

Çizelge I'de sunulmuştur. Farklı ambalajların raf ömrü süresince kuru üzüm tanelerinin $C^{*}$ ve $h^{\circ}$ değerine etkileri birbirine benzerlik göstermiştir. 9 aylık raf ömrü sonunda kuru üzüm tanelerinin $C^{*}$ ve $h^{\circ}$ değerleri sırasıly |5.32-16.95 ve 55.86-59.66 arasında bir değişim göstermiştir. Raf ömrü öncesi 17.73 olan kuru üzüm tanelerinin $C^{*}$ değeri, raf ömrü süresince tüm ambalajlarda çok sınırlı bir değişim ( I5.32-17.| 9) göstermiştir. Raf ömrü başlangıcında 76.13 olan $h^{\circ}$ değeri, 3 , 6 ve 9 aylık raf ömrü sonunda sırasıyla otalama 68.74, 59.26 ve 57.86 olarak saptanmıştır. Raf ömrü süresince bandırılarak kurutulan üzümlerin $C^{*}$ ve $h^{\circ}$ değerindeki değişimlerin belirgin olmamasında, kuru üzümlerin raf ömrü öncesindeki renginin etkili olduğu düşünülmektedir.

Bandırılmış organik kuru üzümlerin ambalajlara göre su miktarı ve $a_{w}$ değeri değişimleri Çizelge 2'de verilmiştir. Farklı ambalajların raf ömrü süresince organik kuru üzüm tanelerinin su miktarı ve $a_{w}$ değerine etkisi önemli $(P \leq 0.0$ I) farklılıklar göstermiştir. Raf ömrü süresince quadro ambalajındaki kuru üzümlerin su miktarı ve $a_{w}$ değeri en yüksek iken, kraft box ambalajındakileri ise en düşük bulunmuştur. 9 aylık raf ömrü sonunda quadro ambalajındaki kuru üzümlerin su miktarı ve $\mathrm{a}_{\mathrm{w}}$ değeri sırasıyla \% I5.19 ve 0.55 iken, kraft box ambalajında ise sırasıyla \% I 3.55 ve 0.49 olarak saptanmıştır. Raf ömrü süresince kuru üzümlerin su miktarında bir azalış eğilimi gözlenirken, $a_{w}$ değerindeki değişimleri sınırlı olmuştur. Raf ömrü öncesi kuru üzümlerin su miktarı ve $a_{w}$ değeri sırasıyla \%।6.12 ve 0.53 olarak belirlenmiştir. Raf ömrü süresince bandırılmış organik kuru üzümlerin su miktarı ve $a_{w}$ değerinde ambalajlara göre saptanan farklılıklarda, ambalajların su geçirgenliğinin etkili olduğu düşünülmektedir. Raf ömrü süresince bandırılmış kuru üzümlerin su miktarı ve $a_{w}$ değerinde görülen azalış, raf ömrü süresi ve koşullarına göre değişmektedir. Nitekim raf ömrü süresinin ilerlemesiyle kuru üzümlerdeki su kaybı, ambalajın nem geçirgenliği ve ortam koşullarına, özellikle de oransal nemin düşük olmasına bağlıdır (Karaçalı, 2002; Cemeroğlu ve ark., 2004). Kuru üzümlerin $a_{w}$ değerindeki değişimler su miktarındaki değişimler ile uyumlu bulunmuştur. Kuru üzümlerin $\mathrm{a}_{\mathrm{w}}$ değerinin, küf gelişimi için riskli değerin $\left(\mathrm{a}_{\mathrm{w}}<0.70\right)$ çok altında olduğu saptanmıştır (Koç ve ark., 20।2).

Raf ömrü süresince ambalajlara göre bandırılmış organik kuru üzümün SÇKM ve TA miktarı değişimleri Çizelge 3'de sunulmuştur. Kuru üzümlerinin SÇKM miktarına ambalajların etkisi 3 aylık raf ömrü sonrası önemli $(P \leq 0.05)$ olurken, ilerleyen raf ömrü dönemlerinde ise önemsiz olmuştur. 3 aylık raf ömrü sonunda kraft box ambalajındaki kuru üzümlerin SÇKM miktarı en yüksek (\%69.33) bulunmuş, quadro ambalajında ise en düşük (\%64.78) bulunmuştur. Ambalajlardaki kuru üzümlerin SÇKM miktarları, 6 ve 9 aylık raf ömrü sonrası sırasıyla \%67.00-69.67 ve \%73.44-74.33 arasında değişmiştir.

Farklı ambalajların raf ömrü süresince bandırılmış organik kuru üzüm meyvelerinin TA miktarına etkisi önemli $(P<0.0 \mathrm{I})$ olmuştur. Pillow pack ambalajındaki kuru üzümlerin TA miktarı en yüksek bulunmuş, 3, 6 ve 9 aylık raf ömrü sonrası TA miktarı sırasıyla I.92, 2.03 ve $2.01 \mathrm{~g}$ tartarik asit/l00 g olarak saptanmıştır. Raf ömrü süresince kraft box, doypack ve quadro ambalajındakilerde TA miktarı en düşük (I.45-I.65 $\mathrm{g}$ tartarik asit/l00 g) bulunmuştur. Lunch box ambalajındaki kuru üzümlerin TA miktarı bu iki grup arasında yer almıştır. Organik kuru üzümlerin SÇKM miktarı, raf ömrü başlangıcına (\%65.03) göre özellikle 9 aylık raf ömrü sonrasında önemli bir artış (\%73.75) göstermiştir. Raf ömrü süresince kuru üzümlerin TA miktarındaki değişimler, başlangıca ( I.6 I g tartarik asit/ I00 g) göre sınırlı olmuştur.

Bandırılmış organik kuru üzümün SÇKM miktarının ambalajlara göre değişiminde, kuru üzümün su içeriği belirleyici olmuştur. Su miktarı düşük olan ambalajlardaki kuru üzümlerde SÇKM miktarının daha yüksek olması beklenen bir gelişmedir (Şen, 2009). Ancak ambalajların SÇKM miktarına olan bu etkisi, raf 
ömrü süresinin ilerlemesiyle kaybolmuştur. Raf ömrü sonunda, başlangıca göre kuru üzümün SÇKM miktarında görülen kısmi artış, su kaybı ile uyumludur. Kuru meyvelerde su kaybıyla birlikte suda çözünür kuru maddelerin miktarında oransal bir artış gözlenmesi beklenen bir gelişmedir. Depolanan kuru meyvelerde raf ömrü süresi ve koşullarına bağlı olarak meydana gelen su kaybı, SÇKM miktarında artışlara neden olabilmektedir (Sen ve ark., 2009; Karaçalı, 2002). Raf ömrü sonunda bandırılmış kuru üzümlerin TA miktarının başlangıca göre bir artış göstermesi de su kaybıyla açıklanabilir.

\section{Bandırılmamış Organik Kuru Üzüm}

Bandırılmadan kurutulan organik kuru üzüm tanelerinin renginde $\left(C^{*}\right.$ ve $h^{\circ}$ değeri) raf ömrü süresince görülen değişimler Çizelge 4'de verilmiştir. Farklı ambalajların raf ömrü süresince kuru üzüm tanelerinin $C^{*}$ değerine etkileri istatistiksel anlamda önemli $(P<0.05)$ olurken, $h^{\circ}$ değerine etkileri önemsiz olmuştur. Pillow pack ambalajdaki kuru üzüm tanelerinin $C^{*}$ değeri en düşük bulunmuş, 3, 6 ve 9 aylık raf ömrü sonrası sırasıyla $9.80,8.63$ ve 8.89 olarak saptanmıştır. Raf ömrü süresince bandırılmamış kuru üzüm tanelerinin $h^{\circ}$ değeri 4l.06 ile 46.66 arasında değişmiştir. Raf ömrü süresince tüm ambalajlardaki kuru üzüm tanelerinin $C^{*}$ ve $h^{\circ}$ değerinde değişimler sınırlı olmuştur. Raf ömrü başlangıcında $C^{*}$ ve $h^{\circ}$ değeri sırasıyla 12.67 ve 47.54 olarak saptanmıştır. Bandırılmamış organik kuru üzüm tanelerinin $C^{*}$ değerinin pillow pack ambalajlarında kısmen daha düşük olması, bu üzüm tanelerinin daha hafif mat-donuk olduğunu göstermektedir. Kuru üzümlerde renk değişimlerinin sınılı olmasında, renk değişimlerindeki enzimatik olmayan reaksiyonların etkili olduğu bildirilmiştir (Karaçalı, 2002; Cemeroğlu ve ark., 2004).

Bandırılmamış organik kuru üzümlerin su miktarına raf ömrü süresince ambalajlara göre değişimleri Çizelge 5'de sunulmuştur. Farklı ambalajların raf ömrü süresince organik kuru üzüm tanelerinin su miktarı ve $a_{w}$ değerine etkisi önemli farklılıklar göstermiştir. Raf ömrü süresince quadro ve doypack ambalajlarındaki kuru üzümlerin su miktarı ve $a_{w}$ değeri en yüksek iken, kraft box ambalajındaki kuru üzümlerin en düşük bulunmuştur. 9 aylık raf ömrü sonunda quadro ve doypack ambalajlarındaki kuru üzümlerin su miktarı sırasıyla \% I5.02 ve \% |4.42 iken, kraft box ambalajındaki kuru üzümlerin su miktarı \% 10.00 olmuştur. Raf ömrü süresince tüm ambalajlarda kuru üzümlerin su miktarında başlangıca (\%16.98) göre bir azalış eğilimi görülmüştür. Kraft box ambalajındaki kuru üzümlerinin $a_{w}$ değerinde raf ömrü sonunda başlangıca göre önemli bir azalış (0.53'den 0.4l'e düşmüş) gözlenirken, diğer ambalajdaki değişimler çok sınırlı olmuştur. Raf ömrü süresince ambalajlara göre bandırılmamış organik kuru üzümlerin su miktarı ve $a_{w}$ değerindeki değişimler, bandırılmış organik kuru üzümlerininkine benzerlik göstermiştir. Kuru üzümlerin su kaybında, ambalajın nem geçirgenliği ve ortam koşulları belirleyici olmuştur.

Raf ömrü süresince bandırılmamış organik kuru üzümün SÇKM ve TA miktarları Çizelge 6'da verilmiştir. Kuru üzümlerinin SÇKM miktarına ambalajların etkisi 3 ve 6 aylık raf ömrü sonrası önemli olurken, 9 aylık raf ömrü sonunda ise önemsiz olmuştur. 3 ve 6 aylık raf ömrü sonunda kraft box ve lunch box ambalajlarındaki kuru üzümlerin SÇKM miktarı en yüksek, quadro ambalajında ise en düşük bulunmuştur. Ambalajların SÇKM miktarı 9 aylık raf ömrü sonrası SÇKM miktarı birbirine benzerlik göstermiş, \%73.44-\%75.67 arasında değişmiştir. Farklı ambalajların raf ömrü süresince organik kuru üzüm meyvelerinin TA miktarına etkisi birbirine benzerlik göstermiştir. 3, 6 ve 9 aylık raf ömrü sonrası TA miktarı sırasıyla I.58-I.68, I.69-1.77 ve I.79-I.83 g tartarik asit/I00 $\mathrm{g}$ arasında değişmiştir. Raf ömrü süresince SÇKM miktarındaki başlangıca göre bir artış gözlenmiş, raf ömrü öncesi \%66.34

Çizelge 4. Farklı ambalajların raf ömrü süresince bandırılmamış organik kuru üzüm tanelerinin $C^{*}$ ve $h^{\circ}$ değerine etkileri

\begin{tabular}{|c|c|c|c|c|c|c|}
\hline \multirow[b]{2}{*}{ Ambalaj } & \multicolumn{3}{|c|}{$C^{*}$} & \multicolumn{3}{|c|}{$h^{\circ}$} \\
\hline & 3. Ay & 6. Ay & 9. Ay & 3. Ay & 6. Ay & 9. Ay \\
\hline Kraft box & $11.84 a^{2 *}$ & $9.94 \mathrm{a}^{*}$ & $10.14 a b^{*}$ & $44.06^{\text {ö.d. }}$ & $43.01^{\text {ö.d. }}$ & $45.06^{\text {o.d. }}$ \\
\hline Doypack & $11.26 \mathrm{ab}$ & $10.00 \mathrm{a}$ & $10.81 \mathrm{a}$ & 46.66 & 45.62 & 44.05 \\
\hline Quadro & $11.05 \mathrm{ab}$ & $9.60 \mathrm{ab}$ & $10.80 \mathrm{a}$ & 42.55 & 45.39 & 44.40 \\
\hline Lunch box & 9.99 b & $10.29 a$ & $9.92 b$ & 41.97 & 41.06 & 46.07 \\
\hline Pillow pack & $9.80 \mathrm{~b}$ & $8.63 b$ & $8.89 b$ & 44.81 & 46.55 & 46.42 \\
\hline
\end{tabular}

zHer sütunda ortalamalar arasındaki farklılıklar Duncan testiyle $P \leq 0.05$ 'e göre belirlenmiştir.

ö.d: önemli değil, * P $\leq 0.05$ 'e göre önemli.

Çizelge 5. Farklı ambalajların raf ömrü süresince bandırılmamış organik kuru üzüm tanelerinin su miktarına ve $a_{w}$ değerine etkileri.

\begin{tabular}{|c|c|c|c|c|c|c|}
\hline \multirow[b]{2}{*}{ Ambalaj } & \multicolumn{3}{|c|}{ Su miktarı (\%) } & \multicolumn{3}{|c|}{$a_{w}$ değeri } \\
\hline & 3. Ay & 6. Ay & 9. Ay & 3. Ay & 6. Ay & 9. Ay \\
\hline Kraft box & $14.36 b^{2 * * *}$ & $13.63 b^{* *}$ & $10.00 c^{*}$ & $0.48 b^{z * * *}$ & $0.46 c^{*}$ & $0.41 c^{*}$ \\
\hline Doypack & $17.44 \mathrm{a}$ & $16.00 \mathrm{a}$ & $14.42 \mathrm{a}$ & $0.54 \mathrm{a}$ & $0.50 \mathrm{~b}$ & $0.52 \mathrm{a}$ \\
\hline Quadro & $17.70 \mathrm{a}$ & $16.08 \mathrm{a}$ & $15.02 \mathrm{a}$ & $0.55 \mathrm{a}$ & $0.54 \mathrm{a}$ & $0.53 \mathrm{a}$ \\
\hline Lunch box & $14.97 \mathrm{~b}$ & $14.35 b$ & $12.92 \mathrm{~b}$ & $0.49 \mathrm{~b}$ & $0.50 \mathrm{~b}$ & $0.47 \mathrm{~b}$ \\
\hline Pillow pack & $15.32 \mathrm{~b}$ & $14.22 b$ & $12.22 \mathrm{~b}$ & $0.49 \mathrm{~b}$ & $0.50 \mathrm{~b}$ & $0.47 \mathrm{~b}$ \\
\hline
\end{tabular}

zHer sütunda ortalamalar arasındaki farklılıklar Duncan testiyle $\mathrm{P} \leq 0.05$ 'e göre belirlenmiştir.

$* P \leq 0.05$, ** $P \leq 0.0$ I'e göre önemli.

Çizelge 6. Farklı ambalajların raf ömrü süresince bandırılmamış organik kuru üzüm tanelerinin SÇKM ve TA miktarına etkileri

\begin{tabular}{|c|c|c|c|c|c|c|}
\hline \multirow[b]{2}{*}{ Ambalaj } & \multicolumn{3}{|c|}{ SCKM miktarı (\%) } & \multicolumn{3}{|c|}{ TA miktarı (g tartarik asit/100 g) } \\
\hline & 3. Ay & 6. Ay & 9. Ay & 3. Ay & 6. Ay & 9. Ay \\
\hline Kraft box & $69.00 \mathrm{a}^{\mathrm{z} * *}$ & $72.33 \mathrm{a}^{*}$ & $75.22^{\text {o.d. }}$ & $1.68^{o ̈ . d .}$ & $1.76^{\text {ö.d. }}$ & $1.82^{\text {ö.d. }}$ \\
\hline Doypack & $65.22 b$ & 69.44 b & 73.89 & 1.58 & 1.69 & 1.81 \\
\hline Quadro & $64.56 \mathrm{~b}$ & $66.12 \mathrm{c}$ & 73.44 & 1.71 & 1.75 & 1.83 \\
\hline Lunch box & $67.67 \mathrm{a}$ & $71.89 \mathrm{a}$ & 75.67 & 1.61 & 1.72 & 1.82 \\
\hline Pillow pack & $65.67 \mathrm{~b}$ & $69.45 \mathrm{~b}$ & 74.56 & 1.64 & 1.77 & 1.79 \\
\hline
\end{tabular}

${ }^{z}$ Her sütunda ortalamalar arasındaki farklılıklar Duncan testiyle $P \leq 0.05$ 'e göre belirlenmiştir.

ö.d. önemli değil, * $P \leq 0.05, * * P \leq 0.01$ 'e göre önemli. 
olan SÇKM miktarı, raf ömrü sonunda ortalama \%74.56 olarak saptanmıştır. Raf ömrü sonunda kuru üzümlerin TA miktarı, başlangıca ( $1.49 \mathrm{~g}$ tartarik asit/l00 g) göre bir artış göstermiştir.

Bandırılmamış organik kuru üzümün SÇKM ve TA miktarının raf ömrü boyunca ambalajlara göre değişimleri, bandırılmış kuru üzümünkine benzerlik göstermiştir. Kuru üzümün SÇKM ve TA miktarındaki değişimleri üzümün su miktarı ile ilişkilendirilmektedir (Sen ve ark., 2009; Karaçalı, 2002).

\section{Kuru Meyvelerde Böcek Gelişimi}

Organik kuru incir, kuru üzüm veya kuru kayısı meyvelerinde yapılan incelemelerde herhangi bir böcek zararının olmadığı saptanmıştır. Bunda kuru meyvelerde yapılan atmosferik koşullarda $\mathrm{CO}_{2}$ uygulaması önemli olmuştur.

\section{SONUÇ}

Sonuç olarak kuru üzümde quadro ambalajında su miktarı en yüksek, kraft box ambalajında en düşük bulunmuştur. Genel olarak raf ömrü sonrası ambalajların organik kuru üzümün rengine ve incelenen diğer kalite parametrelerine etkileri sınırlı olmuştur. Organik kuru üzümün 9 ay süreyle raf ömrü süresince kalitesini koruduğu saptanmıştır. Sonuçlar, organik kuru üzüm için quadro ambalajının önerilebileceği, kraft box ambalajlarında bazı kalite parametreleri ile ilgili sorunlar yaşanabileceğini göstermiştir.

\section{TEŞEKKÜR}

Çalışmadaki organik kuru üzümleri sağlayan ve ürünleri paketleyen Işık Tarım Ürünleri San. ve Tic. A.Ş.'a teşekkür ederiz.

\section{KAYNAKLAR}

Akdeniz B (20II) Geleneksel Usullerde Sultani Çekirdeksiz Üzüm Çeşidinin Kurutulması. Gıda Teknolojileri Elektronik Dergisi 6(I): 13-22.

Altuğ T, Pazır F, Elmacı Y (2003) İşlenmiş Kuru Kayısıların Depolanması Sırasındaki Kalite Değişimleri. TÜBITAK TARP-2573-8 Nolu Proje Sonuç Raporu.

Anonim (1972) TS II25 Meyve ve sebze mamulleri titre edilebilen asit tayini, Ankara, 3 p.

Anonim (1990) Standart Üzüm Çeşitleri Kataloğu. Tarım Orman ve Köyişleri Bakanlığı, Yayın Dairesi Başkanlığı I5, 21 .

Anonim (2016a) Türkiye İstatistik Kurumu. http://www.tuik. gov.tr
Anonim (20 I6b) Ege İhracatçı Birlikleri. http:/ / www.egebirlik. org.tr/bilgi-merkezi-raporlar-kuru-meyve.asp

AOAC (1990) Official Methods of Analysis of the Association of Official Analytical Chemists. I5th edition, Washington, DC.

Cemeroğlu B, Karadeniz F, Özkan M (2004) Kurutma Teknolojisi. In: Cemeroğlu B (ed.), Meyve ve Sebze İşleme Teknolojisi, Cilt II, Başkent Klişe Publisher, Ankara

Demiryürek K (2000) The Analysis of Information Systems for Organic and Conventional Hazelnut Producers in Three Villages of the Black Sea Region, Turkey. PhD Thesis. Reading: The University of Reading, UK.

Demiryürek K, Stopes C, Güzel A (2008) Organic Agriculture: The Case of Turkey. Outlook on Agriculture, 37 (4), 713.

Elmaci Y, Altug T, Pazir F (2008) Quality Changes in Unsulfured Sun Dried Apricots During Storage. International Journal of Food Properties, II:I, I46-157.

Fennema OR ( 1976) Principles of Food Science, Part I. Food Chemistry. Morcel Dekker Inc, New York.

Karaçalı I (2002) Meyve ve Sebze Değerlendirme. Ege Üniversitesi Ziraat Fakültesi Yayınları, 19/5. 263 s.

Koç Güler S, Şen F, Aksoy U (2012) Farklı İşlem Görmüş Kuru Meyvelerde Su Aktivitesinin Değişimi Üzerine Araştırmalar. In: Şen F (Ed.), 5. Bahçe Ürünlerinde Muhafaza ve Pazarlama Sempozyumu, 18- 21 Eylül 2012, /İzmir, 381-388.

McGuire RG (1992) Reporting of Objective Color Measurements. HortScience, 27( I 2): I254- 1255.

Perera CO (2005) Selected Quality Attributes of Dried Foods. Drying Technology, 23:4, 717-730.

Şen F (2009) Meyve ve Sebzelerin Kurutulması. In: Şen F (Ed.), Hasat Sonrası liyi Tarım Uygulamaları, Basım Yayım Matbaacılık San. Tic. Ltd. Şti., İzmir, 89-I I4.

Sen F, Karacali I, Turantas F (2009) Effect of Cold and Fluctuating Storage Conditions on Quality of Dried Apricot. Horticulture Environment and Biotechnology 50(3): $1-6$.

Şen F, Meyvacı KB, Koç S, Aksoy U, Karabat S, Afacan M, Sarılar S (2007) Kuru İncir ve İşlenmiş Bazı Ürünlerinin Farklı Depo Koşullarındaki Kalite Değişimleri ve Raf Ömrünün Belirlenmesi Üzerinde Araştırmalar. In: Güleryüz M (Ed.), Türkiye V. Ulusal Bahçe Bitkileri Kongresi, 04-07 Eylül 2007, Cilt I, 77-8I, Erzurum.

Yeygel M Y (200I) İşlenmiş Natürel Kuru Kayısıların depolanması Sırasında Oluşan Değişmeler. Yüksek Lisans Tezi, Ege Üniversitesi, İzmir. 